\title{
The Court of International Trade's Political Party Diversity Requirement: Unconstitutional under Any Separation of Powers Theory
}

\author{
Adam J. Rappaport $\dagger$
}

The power to appoint federal judges is one of the few components of the Constitution to involve all three branches of the government. The framers considered this power so crucial and potentially dangerous that they explicitly divided it between the President and Congress. The partisan interests of the President, reflected in his chosen nominees, were pitted against the corresponding interests of the Senate, reflected in its unrestrained power to accept or reject those nominees.'

Any effort to circumvent this precise separation of powers therefore should be met with skepticism. And any attempt to alter the balancing of partisan interests is even more dubious. Nevertheless, one unique federal law does exactly this. Beyond residency requirements, the President has unbounded discretion to choose his nominees for the federal bench. But the President is significantly restrained in his selection of nominees to the Court of International Trade ("CIT"). By statute, no more than five of the nine members of the CIT may be from any one political party. ${ }^{2}$

This Comment considers whether this requirement for political party diversity on the CIT violates the Appointments Clause of Article II of the Constitution. ${ }^{3}$ Part I describes the CIT and the evolution of its unique political party diversity requirement. Part II examines formalist and functionalist theories of the separation of powers, other restrictions on the President's power to nominate federal officers, and the scant judicial treatment of such restrictions. Parts III and IV explore in detail the CIT's political party diversity requirement using

$\dagger$ B.A. 1991, Wesleyan University; J.D. 2001, The University of Chicago.

See US Const Art II, \$2, cl 2 (Appointments Clause).

See Court of International Trade Act, Pub L No 106-580, 62 Stat 899 (1948), codified at 28 USC \& 251(a) (1994).

3 This restriction, along with political party diversity requirements imposed on administrative agencies, may also violate First Amendment freedoms of speech and association. This theory is beyond the scope of this Comment, but is explored briefly in Jamin B. Raskin, "A Complicated and Indirect Encroachment": Is the Federal Election Commission Unconstitutionally Composed?, 52 Admin L Rev 609, 623-26 (2000) (arguing that bipartisanship requirements for appointments to the FEC do not survive First Amendment scrutiny). 
formalist and functionalist perspectives on the Appointments Clause, respectively. The Comment concludes that this restriction violates the Appointments Clause under either theory, and argues that functionalism offers a marginally better means of addressing statutory restrictions in general.

\section{EVOLUTION OF THE CIT AND THE POLITICAL DIVERSITY REQUIREMENT}

The CIT is a specialized federal trial court established under Article III of the Constitution. ${ }^{4}$ It has subject matter jurisdiction over civil suits that arise out of agency actions on import transactions; ${ }^{5}$ its geographical jurisdiction extends throughout the United States; ${ }^{6}$ and it ordinarily sits in New York.' The CIT possesses all of the legal and equitable powers of a United States District Court. ${ }^{8}$ The court consists of nine judges who must be appointed by the President with the consent of the Senate. 'Most cases are assigned to a single CIT judge. ${ }^{10}$ The chief judge establishes a three judge panel for cases that involve the constitutionality of an act of Congress, a presidential proclamation, or an executive order, or for those that have broad and significant implications in the administration or interpretation of the customs laws." CIT decisions may be appealed to the Court of Appeals for the Federal Circuit, and from there to the Supreme Court."

The organic statute establishing the CIT contains a unique provision. It mandates that "[n]ot more than five of such judges shall be from the same political party." ${ }^{13}$ While similar political party diversity requirements are not uncommon for administrative bodies, ${ }^{14}$ the CIT sition).

4 See 28 USC $\$ 251$ (a) (authorizing the CIT under Article III and establishing its compo-

5 See Gregory W. Carman, The Jurisdiction of the United States Court of International Trade: A Dilemma for Potential Litigants, 22 Stetson L Rev 157, 160-62 (1992) (describing the composition and jurisdiction of the CIT). See also Matt Valitchka, Comment, Customs Courts Act of 1980: An Evaluation and Analysis, 4 Hamline L Rev 538-39 (1981) (describing jurisdiction of the United States Customs Court, the immediate predecessor of the CIT); Paul P. Rao, Comment, A Primer on Customs Court Practice, 40 Brooklyn L Rev 581, 584-87 (1974) (describing jurisdiction and practice of the Board of General Appraisers and the U.S. Customs Court, predecessors of the CIT).

6 See Carman, 22 Stetson L Rev at 160 (cited in note 5) (noting that the CIT is a national trial court).

728 USC \& 251(c).

8 See Carman, 22 Stetson L Rev at 161 (cited in note 5).

928 USC $\$ 251(a)$.

1028 USC $\$ 254$ (1994).

1128 USC $\$ 255$ (1994).

12 See 28 USC $\$ 1295$ (a)(5) (1994) (governing appeals from final decisions of the CIT); 28 USC $\$ 1292$ (d)(1) (1994) (governing appeals of interlocutory orders of the CIT).

1328 USC $\$ 251(\mathrm{a})$.

14 See note 88 . 
is the only Article III court with such a restriction. ${ }^{15}$ This Section examines the history and jurisdiction of the CIT in general and the evolution of its political party restriction.

\section{A. History of the CIT}

The original predecessor of the modern Court of International Trade came into existence in 1890 as the Board of General Appraisers, a quasi-judicial administrative body within the Treasury Department. Congress created the Board in response to inconsistent assessments of import duties at various United States ports and to the increase in litigation over customs decisions that clogged state and federal courts." Granted original jurisdiction over all cases concerning the application of tariff laws, ${ }^{18}$ the Board reviewed decisions by customs officials on the classification and valuation of imported goods."

Congress replaced the Board in 1926 with the United States Customs Court, ${ }^{20}$ which it established under Article I of the Constitution. ${ }^{21}$ The change was in name only, as essentially no changes were made in the tribunal's functions, duties, or jurisdiction. ${ }^{22}$ Over the next thirty years, Congress gradually integrated the Customs Court into the federal court system. ${ }^{23}$ Congress completed this process in 1956 by designating it a court under Article III.

15 See Customs Courts Act of 1980, S 1654, 96th Cong, 2d Sess, in 126 Cong Rec S 27063-64 (Sept 24, 1980) (statement of Senator DeConcini) (noting CIT's party restrictions as unique among Article III courts).

16 Act of June 10,1890, 26 Stat 131, 136.

17 Rao, Comment, 40 Brooklyn L Rev at 585 (cited in note 5) (describing creation of the Board of General Appraisers as an attempt to overcome problems of expanding trade in a rapidly growing nation).

18 Id.

19 See Customs Courts Act of 1980, HR 7540, 96th Cong, 2d Sess, in 126 Cong Rec H 26553-54 (Sept 22, 1980) (statement of Representative Rodino) ("Because customs duties were the principal source of revenue for the Government, the tariff statutes and the corresponding administrative procedures were designed to maximize the Government's ability to collect such duties with a minimal emphasis on judicial review.").

20 Act of May 28, 1926, Pub L No 69-304, 44 Stat 669.

21 See 126 Cong Rec H at 26553 (cited in note 19) (statement of Representative Rodino) (describing new Customs Court as an Article I court). The Supreme Court later confirmed the Article I status of both the Board and the court. See Ex Parte Bakelite Corp, 279 US 438, 457-58 (1929) ("[I]ts functions, although mostly quasijudicial, were all susceptible of performance by executive officers."). See also Carman, 22 Stetson L Rev at 158 (cited in note 5) (same).

22 See Rao, Comment, 40 Brooklyn L Rev at 586 (cited in note 5). See also 126 Cong Rec $\mathrm{H}$ at 26553 (cited in note 19) (statement of Representative Rodino) ("In fact, the court continued to function in most matters as would have its predecessor in reviewing the actions of the Bureau of Customs.").

23 See Tariff Act of 1930, Pub L No 71-361, 46 Stat 590, 738 (transferring maintenance and operation of court from Secretary of the Treasury to Attorney General); Act of Aug 7, 1939, Pub L No 76-299, 53 Stat 1223, 1225 (bringing court within the supervision of the Administrative Office of the United States Courts); Act of June 25, 1948, Pub L No 80-773, 62 Stat 869, 943 (integrating the court into the structure, organization, and procedures of the United States court 
Despite the adjustments, problems with the role and jurisdiction of the court developed in the 1960s. Worldwide decreases in tariff rates diminished the importance of the court's classification and valuation duties, and the patchwork of laws governing emerging trade issues increasingly led parties to contest government decisions in federal district courts. ${ }^{25}$ Congress first addressed these issues in the Customs Courts Act of 1970 and the Trade Agreements Act of 1979. ${ }^{26}$ Congress made more fundamental changes to the court's jurisdiction and procedure in the Customs Courts Act of $1980{ }^{27}$ At present, the court

system).

24 Act of July 14, 1956, Pub L No 84-703, 70 Stat 532 . Congress specified that the act did not change the court's jurisdiction. Id. Courts established by Congress under Article III are limited by the jurisdictional provisions of Article III, and judges of these courts are guaranteed lifetime tenure and salary protection. Ronald D. Rotunda and John E. Nowak, Treatise on Constitutional Law $\$ 2.1$ at 75 (West 1999). Congress has also established Article I courts, called legislative courts. These courts are not constrained by Article III's jurisdictional.provisions, and judges of these courts do not receive the Article III protections. Id at 75-76. "These Article I tribunals are really akin to administrative agencies." Id at 76 . Article I courts generally fall into three categories: courts established to adjudicate public rights, such as the United States Tax Court and federal bankruptcy courts; territorial courts; and military tribunals. See Richard H. Fallon, Jr., of Legislative Courts, Administrative Courts, and Article III, 101 Harv L Rev 916, 921-22, 971-74 (1988). Like administrative agencies, some Article I courts have appointment restrictions. See note 82 .

25 Limited by its organic statutes, the court had "not kept pace with the increasing complexities of modern day international trade litigation." Customs Courts Act of 1980, HR Rep No 96-1235, 96th Cong, 2d Sess 18-19 (1980), reprinted in 1980 USCCAN 3729, 3730-31. Designed to review classification and valuation determinations, the court's jurisdiction had remained essentially unchanged since its origin as the Board of General Appraisers, a period in which tariff rates were the central factor in international trade. As a result, the court had limited remedy options: in most cases, it could only agree or disagree with an administrative decision, and it could not issue money judgments or provide equitable relief. As tariff rates declined, cases involving antidumping and countervailing duty statutes gained greater importance. Unsure whether the Customs Court had jurisdiction over these cases, and concerned about the limited powers of the court, litigants increasingly filed challenges in federal district court. This led to inconsistent decisions and high uncertainty among litigants. Id. See also 126 Cong Rec at S 27063 (statement of Senator DeConcini) (cited in note 15) (describing problems with the Customs Court's jurisdiction and procedures); Richard A. Cohen, The New United States Court of International Trade, 20 Colum J Transnatl L 277, 278-82 (1981) (same); Valitchka, Comment, 4 Hamline L Rev at 540-44 (cited in note 5) (same).

26 Customs Courts Act of 1970, Pub L No 91-271, 84 Stat 274, 275-76 (making adjustments to the court's procedures); Trade Agreements Act of 1979, Pub L No 96-39, 93 Stat 144, 150-89 (giving the court limited authority to grant equitable remedies and creating new causes of action within the court's jurisdiction on antidumping and countervailing duty questions). See also Cohen, 20 Colum J Transnatl $\mathrm{L}$ at 281-82 (cited in note 25) (summarizing changes in Trade Agreements Act of 1979).

27 Customs Courts Act of 1980, Pub L No 96-417, 94 Stat 1727, codified in various sections of title 28 (1994) (expanding and clarifying the court's subject matter jurisdiction, altering its procedures, and granting it equitable powers of money and injunctive relief). See also Cohen, 20 Colum J Transnatl L at 282-92 (cited in note 25) (explaining reforms in $1980 \mathrm{act}$ ). 
has authority over the classification and valuation of merchandise, the charging of duties and fees on the importation of merchandise, the exclusion of merchandise from entry under provisions of the customs laws, the liquidation of entries, the refusal to pay drawback, and challenges to antidumping and countervailing duty decisions.

The court also "has jurisdiction to review the denial, revocation, or suspension of a customs broker's license, determinations of eligibility for trade adjustments under the Trade Act of 1974, and penalty cases. ${ }^{929}$ The Customs Courts Act of 1980 clarified that the CIT has the same powers in law and equity as any other Article III court. ${ }^{30}$ The Act also again renamed the court, this time as the United States Court of International Trade.

\section{B. Evolution of the CIT's Political Party Diversity Requirement}

The original 1890 statute creating the Board of General Appraisers instructed the President to appoint nine general appraisers of merchandise, by and with the advice and consent of the Senate. ${ }^{32}$ It further stipulated that "[n]ot more than five of such general appraisers shall be appointed from the same political party., ${ }^{, 33}$ As the status and jurisdiction of the court evolved through 1980 , the political party diversity requirement remained intact and apparently unquestioned.

Congress debated the wisdom and legitimacy of the political party diversity requirement during the drafting and passage of the 1980 Act, but in the end it retained the provision. The first version of the bill eliminated the restriction, and passed the Senate with little

28 Carman, 22 Stetson L Rev at 161 (cited in note 5) (citations omitted).

29 Id (citations omitted).

30 HR Rep No 96-1235 at 20 (cited in note 25).

31 Customs Courts Act of $1980 \S 101,94$ Stat at 1727.

32 Act of June 10, 1890, 26 Stat at 136.

33 Id. A handful of other administrative boards and commissions established prior to the Board of General Appraisers included a similar political party restriction. The first political party diversity requirement appears to have been imposed on the board of elections for the Utah Territory Act of Mar 22, 1882, 22 Stat 30,32 (explaining that the president should appoint five board members, "not more than three of whom shall be members of one political party"). See Myers $v$ United States, 272 US 52, 270 n 51 (1926) (Brandeis dissenting) (listing agencies with political party restrictions). The diversity requirement was soon extended to the Civil Service Commission, Act of Jan 16, 1883, 22 Stat 403 (requiring that only two of three commissioners come from the same political party), the Interstate Commerce Commission, Act of Feb 4, 1887, 24 Stat 379, 383 (permitting only three of five commissioners to share the same political party), and the Federal Trade Commission, Act of Sept 26, 1914, 38 Stat 717, 717-18 (same).

34 However, the title of the restricted individuals changed first from "general appraisers" to "justices," Act of May 28, 1926, 44 Stat at 669, then from "justices" to "judges." Tariff Act of 1930, 46 Stat at 737. 
controversy. ${ }^{35}$ The sponsor, Senator Dennis DeConcini, later explained the policy rationales for deleting the requirement. First, he noted that the provision is a vestige of the court's original Article I status and argued that judges of an Article III court should be appointed on merit alone. ${ }^{36}$ Second, DeConcini argued that the restriction would tend to politicize the court. ${ }^{37}$

Following the Senate's lead, the original House bill also eliminated the requirement. ${ }^{38}$ During a House Judiciary subcommittee hearing on the bill, however, Representative Robert McClory defended the provision as an effective way to keep the membership of the court politically balanced. ${ }^{39}$ After some additional legislative maneuvering, the House and Senate passed a final version of the bill that included the political diversity requirement. ${ }^{40}$

Congress subtly changed the political diversity language during this process. It deleted "appointed" from the provision, leaving it as: "Not more than five of such judges shall be from the same political party.", There is no record of why Congress altered the language, but the modification does not change the statute's effect. The restriction limits the prior sentence, which instructs the President to appoint nine judges to the CIT by and with the advice and consent of the Senate. Congress has not subsequently altered the provision.

\section{RESTRICTIONS ON FEDERAL OFFICERS AND THE APPOINTMENTS CLAUSE}

The political diversity requirement of the CIT is one of many statutory restrictions on appointment to federal office. By limiting the President's power under the Appointments Clause of Article II, these restrictions may pose separation of powers problems. Two main theo-

35 Customs Courts Act of 1979, S 1654, 96th Cong, 1st Sess, in 125 Cong Rec S 36624, 36625-31 (Dec 18, 1979).

36126 Cong Rec at S 27064 (cited in note 15).

37 Id. Nevertheless, Senator DeConcini said he thought the provision was constitutional. Customs Courts Act of 1980, Hearings on HR 6394 before the Subcommittee on Monopolies and Commercial Law of the House Judiciary Committee, 96th Cong, 2d Sess 5 (1980) (responding "no" when asked whether it was his position that the existing law was unconstitutional).

38 HR Rep No 96-1235 at 30 (cited in note 25).

39 Hearings on HR 6394, 96th Cong, 2d Sess at 13 (cited in note 37). Representative McClory, a Republican, argued that 90 percent of the federal judges nominated by President Carter were Democrats, while President Ford "had a balance of 60/40 or so." Id. The requirement would "ameliorate partisan considerations by requiring a President on occasion to look outside his party for qualified candidates." HR Rep No 96-1235 at 134 (cited in note 25) (additional views of Representatives Robert McClory, Tom Railsback, Henry J. Hyde, and James Sensenbrenner, Jr.).

40 See 126 Cong Rec H 26555 (Sept 22, 1980) (House passage of bill with requirement); 126 Cong Rec S 27064 (Sept 24, 1980) (Senate concurrence in House bill).

4128 USC $\$ 251(a)$.

42 Id. 
ries are used to interpret constitutional provisions that implicate the separation of powers: formalism and functionalism. These theories are reflected in the few opinions that address the constitutional status of statutory restrictions on appointment. This Part examines these theories and their application, and concludes that the analysis in the cases is not sufficient to determine if the CIT's political party restriction violates the Appointments Clause.

\section{A. Formalist and Functionalist Perspectives of the Appointments Clause}

The Appointments Clause of Article II establishes the method for selecting federal government officers. The clause states:

[The President] shall nominate, and by and with the Advice and Consent of the Senate, shall appoint Ambassadors, other public Ministers and Consuls, Judges of the Supreme Court, and all other Officers of the United States, whose Appointments are not herein otherwise provided for, and which shall be established by Law: but the Congress may by Law vest the Appointment of such inferior Officers, as they think proper, in the President alone, in the Courts of Law, or in the Heads of Departments.

The Clause does not explicitly address restrictions on and qualifications for federal offices, leaving it open to a variety of interpretations. The Clause arose out of the framers' desire to divide the power to appoint federal officers - a power they believed essential to the efficient operation of government-between the executive and legislative branches. ${ }^{44}$

Separation of powers issues are usually interpreted using two distinct theories. ${ }^{45}$ Formalism sees the text of the Constitution as clearly dividing the three branches of government, with overlapping power only in the few areas where the text expressly authorizes it. ${ }^{46}$ This view

43 US Const Art II, $\$ 2$, cl 2. Federal judges who serve on Article III courts such as the CIT clearly qualify as principal or superior officers who must be nominated by the President and confirmed by the Senate. See Edmond v United States, 520 US 651, 667 (1997) (Souter concurring) ("United States district judges cannot be inferior officers, since the power of appellate review does not extend to them personally, but is limited to their judgments.").

44 See Federalist 76 (Hamilton), in Clinton Rossiter, ed, The Federalist Papers 456-58 (New American Library 1961) (discussing the advantages of dividing the power to nominate and appoint between the President and the Senate).

45 Consider Peter L. Strauss, Formal and Functional Approaches to Separation-of-Powers Questions - A Foolish Inconsistency?, 72 Cornell L Rev 488, 489 (1987) (noting the Court's vacillation between formalism and functionalism). For a good list of formalist and functionalist commentary, see M. Elizabeth Magill, The Real Separation in Separation of Powers Law, $86 \mathrm{Va} \mathrm{L}$ Rev 1127, 1137 n 35 (2000). For a classification of Supreme Court cases, see id at 1138 n 37.

46 See Martin H. Redish and Elizabeth J. Cisar, "If Angels Were to Govern": The Need for Pragmatic Formalism in Separation of Powers Theory, 41 Duke L J 449, 455 n 24 (1991) (observ- 
is rooted in the Constitution's separation of powers into the first three distinct articles, and in the vesting clauses that assign certain powers to each branch. ${ }^{47}$ This textual and structural separation allows each branch to act as a check on the power of the others, but only through the avenues authorized by the Constitution. Any apportionment of power outside of these avenues, therefore, violates the Constitution. Because it is based on the distribution of power that the framers established, formalism for the most part interprets constitutional ambiguities only through tools that reflect that original distribution. ${ }^{49}$ Formalism thus focuses primarily on the text and structure of the Constitution. Interpreters may also use contemporary accounts of original intent, such as debates in the Constitutional Convention and the Federalist Papers. ${ }^{50}$ Longstanding and unchallenged legislative enactments that commence soon after ratification can also demonstrate original intent. ${ }^{\text {st }}$

Formalist thinking is prominent in many leading separation of powers cases. For example, the Court strictly adhered to the text of the Constitution in striking down the legislative veto in INS $v$ Chadha. The Court reasoned that allowing one chamber of Congress to overturn an executive branch decision failed to conform to the "[e]xplicit and unambiguous" textual mandates of bicameralism and presentment. ${ }^{53}$ Clinton $v$ City of New York ${ }^{\text {s4 }}$ rested on a similarly formalist rationale - that there was no textual basis for allowing the President in effect to repeal statutes through a line item veto. ${ }^{55}$

ing that separation of powers protections are embodied in the text itself).

47 Id. See also Rebecca L. Brown, Separated Powers and Ordered Liberty, 139 U Pa L Rev 1513, 1523-24 (1991).

48 See, for example, id at 1526-27 \& n 55 (describing interbranch competition through strictly defined methods in matters of foreign affairs).

49 See William N. Eskridge, Jr., Relationships between Formalism and Functionalism in Separation of Powers Cases, 22 Harv J L \& Pub Pol 21, 21 (1998) (noting formalism's "deduction from authoritative ... original intent").

50 Antonin Scalia, A Matter of Interpretation: Federal Courts and the Law 38 (Princeton 1997) (stating that he consults The Federalist because it "display[s] how the text of the Constitution was originally understood").

51 See text accompanying notes $164-69$.

52462 US 919, 945 (1983) ("Explicit and unambiguous provisions of the Constitution prescribe and define the respective functions of the Congress and of the Executive in the legislative process.").

53 Id at 945-51.

54524 US 417 (1998).

55 Id at 438-40 (describing the line item veto as outside of the "'finely wrought' procedure" designed by the framers), citing INS v Chadha, 462 US 919, 951 (1983). Other formalist examples include Bowsher v Synar, 478 US 714 (1986), in which the Court invalidated the GrammRudman-Hollings Act because it gave Congress removal power over an official performing executive duties, and Metropolitan Washington Airports Authority $v$ Citizens for the Abatement of Aircraft Noise, Inc, 501 US 252 (1991), which held unconstitutional an airport advisory body that included members of Congress. Id at 277. See also Magill, 86 Va L Rev at 1138 n 37 (cited in note 
On the other hand, functionalism envisions extensive interaction and overlap among the three branches of government. Instead of rejecting all assertions of power outside of those explicitly authorized by the text, functionalism adopts a balancing approach that compares the extent to which one branch's action prevents another branch from exercising its constitutionally assigned power with the policy justification for that action. ${ }^{56}$ Thus, if the policy justification trumps the degree of encroachment on another branch, the action is constitutional. ${ }^{57}$ Functionalists therefore consider not only the text, structure, and representations of original intent, but also policy arguments unrelated to formalist sources.

The Court has also used functionalism in recent decisions to allow overlap between the branches of government. Most prominently, the Court used a functionalist balancing test in Morrison v Olson ${ }^{39}$ to uphold the constitutionality of the independent counsel. ${ }^{60}$ To determine whether the independent counsel was a principal or inferior officer, the Court weighed four different policy factors. ${ }^{61}$ Likewise, Mistretta $v$ United States ${ }^{62}$ upheld the United States Sentencing Commission-a policymaking body - even though Congress placed it in the judicial branch and required that three of its seven members be sitting federal judges.

45) (classifying Clinton v City of New York, Metropolitan Washington Airports Authority, Bowsher, and Chadha as formalist opinions).

56 See Nixon $v$ Administrator of General Services, 433 US 425, 443 (1977) (using this balancing test to determine that a statute that directed an executive branch official to take custody of a former president's papers did not violate the separation of powers).

57 Id (holding that when a statute might prevent one branch "from accomplishing its constitutionally assigned functions," courts must determine "whether that impact is justified by an overriding need to promote objectives within the constitutional authority of Congress"). See also Mistretta v United States, 488 US 361, 393 (1989) (balancing the "practical consequences" of placing a policymaking commission within the judicial branch against the threat of undermining the integrity of the that branch or expanding its powers beyond constitutional bounds); Richard $\mathrm{P}$. Wulwick and Frank J. Macchiarola, Congressional Interference with the President's Power to Appoint, 24 Stetson L Rev 625, 642 (1995) (describing functionalism as "balanc[ing] the extent to which one branch's actions disrupt the traditional delegation of power against the public policy that might justify this disruption").

58 See, for example, Mistretta, 488 US at 396 (justifying the placement of a policymaking commission in the judicial branch on the policy grounds of that branch's "special knowledge and expertise").

$59 \quad 487$ US 654 (1988).

60 Id at 696-97 ("[T]he Act does not violate the separation-of-powers principle by impermissibly interfering with the functions of the Executive Branch.").

61 Id at 671-72. The four factors are whether the officer is subject to removal by a higher officer, limited in duties, limited in jurisdiction, and limited in tenure.

62488 US 361 (1989).

63 Id at 395-97,408 ("[W]e do not believe ... that the placement within the Judicial Branch of an independent agency charged with the promulgation of sentencing guidelines can possibly be construed as preventing the Judicial Branch 'from accomplishing its constitutionally assigned functions."'), citing Nixon, 433 US at 443. 
The Court continues to use both theories in separation of powers cases, but formalism appears to be ascendant. This trend is exemplified by the decision to eschew Morrison's balancing approach in favor of a textual rule in Edmond $v$ United States. ${ }^{64}$ Members of the Court had a fairly clear choice between functionalist and formalist tests, and picked formalism. ${ }^{65}$ Nevertheless, even if formalism is on the rise, the Court has not explicitly chosen one theory over the other. ${ }^{66}$ Just eight days after deciding Edmond, the Court approvingly cited Morrison, Mistretta, and Nixon $v$ Administrator of General Services ${ }^{67}$ in another separation of powers case. ${ }^{68}$ Since justices on the Court continue to use and advocate both theories, this Comment will analyze the CIT's political party restriction from both perspectives.

\section{B. Statutory Restrictions on Appointments to Federal Office}

Although the CIT's political party restriction is unique among Article III courts and has never been challenged, many federal offices have qualifications for membership. The Constitution itself limits the range of people who may serve as President or as a member of the Senate or House..$^{70}$ The First Congress passed statutory qualifications for some federal offices and successive Congresses have instituted many more. Among its other achievements, the Judiciary Act of 1789 created the office of the Attorney General, and provided for District Attorneys." Each of these government attorneys was to be "a meet person learned in the law," limiting the President in his nomination

64520 US 651, 662-63 (1997) (holding judges of the Coast Guard Court of Criminal Appeals to be inferior officers because they have superiors).

65 See Nick Bravin, Note, Is Morrison v. Olson Still Good Law? The Court's New Appointments Clause Jurisprudence, 98 Colum L Rev 1103, 1120 (1998) (arguing that in Edmond, Justice Scalia's formalist majority opinion and Justice Souter's functionalist concurrence offered the justices a clear choice between the theories).

66 Some commentators believe the Court is more formalist when faced with legislative aggrandizement and more functionalist when confronted with other potential separation of powers problems. See Peter S. Guryan, Note, Reconsidering FEC v. NRA Political Victory Fund through a Bolstered Functionalism, 81 Cornell L Rev 1338, 1347-48 (1996) (positing such a theory). Indeed, the Court was formalist when confronted with genuine legislative aggrandizement in INS v Chadha and Clinton $v$ City of New York. This distinction does not explain Edmond, in which the Court took a formal approach in 1997 regarding the same issue about which it used functionalism in 1988. If the distinction is correct, however, the Court should be more likely to use formalism if it is faced with a statutory restriction.

67433 US 425 (1977).

68 Clinton $v$ Jones, 520 US 681, 701 \& n 35 (1997) (observing that "[o]f course the lines between the powers of the three branches are not always neatly defined").

69 See Parts III and IV.

70 US Const Art II, $\S 1$, cl 4 (setting qualifications for the presidency); US Const Art I, § 3, cl 3 (setting qualifications for Senate membership); US Const Art I, $§ 2, \mathrm{cl} 2$ (setting qualifications for House membership).

711 Stat 73.

72 Id at 92-93. 
decision. ${ }^{73}$ The Judiciary Act also required that federal district court judges reside in the district for which they were appointed.

The imposition of statutory qualifications and restrictions has continued unabated. ${ }^{75}$ Being "learned in the law" was the first of many qualifications and restrictions related to professional status and credentials. For example, Congress has required appointees to be members of the bar of a federal court or a state's highest court, ${ }^{76}$ versed in Spanish and English, ${ }^{77}$ engineers, ${ }^{78}$ persons with demonstrated knowledge in futures trading or commodities, ${ }^{79}$ and unconnected with a credit union. ${ }^{80}$ Citizenship, residency, and geographic qualifications have also been common. Some statutes have also required that the President's nominees come from a particular branch or department of the government ${ }^{82}$ or from civilian life. ${ }^{83}$ Congress has also required that

73 See David P. Currie, The Constitution in Congress: The Federalist Period 1789-1801 43 (Chicago 1997) (noting that the requirement "significantly sensibly restricted the President's discretion in selecting" the Attorney General and district attorneys); Susan Low Bloch, The Early Role of the Attorney General in Our Constitutional Scheme: In the Beginning There Was Pragmatism, 1989 Duke L J 561, 567 n 24,571 n 32 (discussing competing interpretations of the Judiciary Act of 1789's appointment provisions); Julius Goebel, Jr., 1 History of the Supreme Court of the United States 490 (Macmillan 1971) (discussing aspects of those provisions). Later statutes extended this requirement to newly created United States Attorneys and several other federal officers who dealt with legal issues. See Myers $v$ United States, 272 US 52, 267-69 n 43 (1926) (Brandeis dissenting). The Attorney General and United States Attorneys are no longer required to be learned in the law. However, the qualification still applies to the Solicitor General. See Act of Sept 6, 1966, Pub L No 89-554, 80 Stat 378, 612, codified at 28 USC $\$ 505$ (1994).

741 Stat 73

75 For an exhaustive list of congressionally imposed qualifications and restrictions on presidential appointees through 1926, see Myers, 272 US at 265-74 nn 35-56.

76 See, for example, 10 USC $\S 942$ (b)(3) (1994) (regulating appointments to the United States Court of Appeals for the Armed Forces).

77 See, for example, Act of Mar 3, 1851, 9 Stat 631 (governing appointments of agents to California Land Commission). See also Myers, 272 US at 267-69 n 43 (listing positions with language requirements).

78 See, for example, Act of Aug 24, 1912, Pub L No 62-334, 37 Stat 512, 517 (stipulating qualifications for officers who may oversee the Alaskan Railroad Commission). See also Myers, 272 US at 267-69 n 43 (listing positions with engineering requirements).

79 See, for example, 7 USC $\& 4 a(a)(1)(i)$ (1994) (mandating demonstrated knowledge before appointment to the Commodity Futures Trading Commission). Even members of the Federal Reserve Board were at one time required to be appointed with "due regard to a fair representation of the financial, agricultural, industrial, and commercial interests, and geographical divisions of the country." Act of Jun 3, 1922, Pub L No 67-230, 42 Stat 620.

80 See, for example, 12 USC $\$ 1752 a(b)(2)(B)$ (1994 \& Supp 1999) (stating the requirements for the National Credit Union Administration Board).

81 See, for example, 28 USC $\$ 44$ (c) (1994 \& Supp 1998) (requiring that most federal circuit court judges "be [ ] resident[s] of the circuit for which appointed at the time of [their] appointment and thereafter while in active service"); 28 USC \& 134(b) (1994 \& Supp 1998) (requiring that most federal district court judges "reside in the district or one of the districts for which [they are] appointed"); 47 USC $\S 154$ (b)(1) (1994) (stipulating that each member of the Federal Communications Commission "shall be a citizen of the United States"). See also Myers, 272 US at 265-67 nn 35-42, 272-73 n 54 .

82 See Myers, 272 US at 273-74 n 55 (listing positions requiring representatives from particular departments). 
the President choose a nominee from a list provided by others such as Congress $^{84}$ or industry and labor. ${ }^{85}$ In addition, the President may not appoint a relative to an agency over which he exercises jurisdiction. ${ }^{86}$

Political party restrictions also limit the President's choice of nominees to numerous commissions, boards, and Article I courts. These bipartisanship requirements emerged in the 1880 s alongside the creation of precursors to independent agencies. ${ }^{87}$ With the growth of the administrative state, the President is constrained in nominating officials of agencies that govern a broad range of activities. ${ }^{88}$ As noted above, however, the CIT is the only Article III court to have a political party diversity requirement. ${ }^{89}$

\section{Judicial Treatment of Restrictions}

Considering the wide use of restrictions and qualifications of appointees, it is surprising how rarely courts have addressed the potential constitutional issues. Federal courts have issued few clear opinions on the requirements for appointment, and none has thoroughly analyzed the question. More specifically, the CIT's political party restriction has apparently never been raised in court.

\section{Restrictions in general.}

The Supreme Court's most direct analysis of the issue came in Justice Kennedy's concurrence in Public Citizen $v$ United States Department of Justice. ${ }^{90}$ The case questioned whether the Federal Advisory Committee Act ("FACA") applied to the American Bar Associa-

83 See, for example, 10 USC $\$ 942$ (b)(1) (1994) (requiring civilian appointments to the United States Court of Appeals for the Armed Forces).

84 See, for example, 31 USC $\$ 703$ (a) (1994) (mandating that Comptroller General and Deputy Comptroller General shall be appointed by the President from a list of at least three individuals recommended by a commission of congressional leaders). See also Bowsher $v$ Synar, 478 US 714,727-28 \& n 6 (1986) (noting this method of appointment).

85 See, for example, Transportation Act of 1920, Pub L No 66-152, 41 Stat 456, 470 (requiring that three members of the Railroad Labor Board be appointed from the employees' list of at least six nominees, and that three be appointed from the carriers' list of at least six nominees).

865 USC \$ 3110(b) (1994) (antinepotism law).

87 See note 33 .

88 One commentator noted at least thirteen administrative agencies with political party diversity requirements, although there certainly are more. Raskin, 52 Admin L Rev at 621-22 \& n 51 (cited in note 3). See, for example, 47 USC $\$ 154$ (b)(5) (Federal Communications Commission); 15 USC \& 78(a) (1994) (Securities and Exchange Commission); 42 USC \& 5841(b)(2) (1994) (Nuclear Regulatory Commission); 10 USC \& 942(b)(3) (1994) (United States Court of Appeals for the Armed Forces); 39 USC $\S 3601$ (a) (1994) (Postal Rate Commission); 5 USC $\S$ 1201 (1994) (Merit Systems Protection Board); 49 USC § 1111(b) (1994) (National Transportation Safety Board).

89 See text accompanying note 15 .

90491 US 440, 482-89 (1989) (Kennedy concurring) (discussing the appointment power from a separation of powers perspective). 
tion's Standing Committee on the Federal Judiciary, which advised the Justice Department on nominees to the federal bench. ${ }^{91}$ The majority did not reach the constitutional questions raised by the participation of an advisory committee in the appointment process, but Justice Kennedy argued that applying FACA's open meetings and public records requirements to the ABA panel would unconstitutionally interfere with the President's exclusive responsibility under the Appointments Clause by inhibiting his freedom to investigate and evaluate potential nominees. ${ }^{93}$ Embracing a formalist viewpoint, Justice Kennedy first argued that the text of the Appointments Clause explicitly committed the nomination power to the President, and that "[n]o role whatsoever is given either to the Senate or to Congress as a whole in the process of choosing the person who will be nominated for appointment." the framers intended Congress's only role in the appointment process to be the Senate's power to give or withhold its advice and consent." Therefore, he concluded, any statutory expansion of that power must be unconstitutional. ${ }^{96}$

Despite this analysis, no court has ever invalidated a statutory restriction on appointments to federal office. Instead, a handful of courts have followed a functionalist approach advocated in one Supreme Court case that did not directly deal with the issue. Chief Justice Taft's majority opinion in Myers $v$ United States ${ }^{98}$ found Congress to have the authority to set qualifications for federal office under some conditions. Using its legislative power, Congress may establish offices, determine their functions and jurisdiction, fix their term and compensation, and prescribe "reasonable and relevant qualifications and rules of eligibility of appointees." This test should allow courts to

91 Id at 443-47 (majority opinion).

92 Id at 443 (deciding the case on the grounds that FACA did not to apply to the ABA committee).

93 Id at 488-89 (Kennedy concurring).

94 Id at 483 .

95 Id, citing Federalist 66 (Hamilton) and Federalist 76 (Hamilton), in Rossiter, ed, The Federalist Papers at 405, 456-57 (cited in note 44).

96 Public Citizen, 491 US at 487-88 (Kennedy concurring).

97 The closest the Court has come was to invalidate a statute passed by the legislature of the Philippines (then a U.S. possession) that allowed the legislature to appoint members of certain state-run corporations. Springer v Government of the Philippine Islands, 277 US 189 (1928). The Court held that the legislature violated the separation of powers inherent in its constitutionlike organic act by placing the appointment power in the legislature. Id at 201-03. However, Springer does not address restrictions on nomination, only the rare situation in which a legislature attempts to grant itself the full power of appointment.

98272 US 52 (1926).

99 Id at 129. Taft based this analysis of legislative power on a statement by James Madison to the First Congress. Id at 128-29. However, Madison stated that the legislature only "creates the office, defines the powers, limits its duration and annexes a compensation. This done, the 
balance policy goals represented by reasonable and relevant qualifications against the extent of encroachment on the President's power to nominate.

A few other cases reflect Taft's functionalist view. Referring generally to Myers, Justice Stevens's concurrence in Bowsher v Synar ${ }^{100}$ stated that "it is entirely proper for Congress to specify the qualifications for an office that it has created." ${ }^{101}$ Taft's position also received support in United States $v$ Espy, ${ }^{102}$ which held that "[a]lthough there are constitutional limits to the qualifications Congress can impose on presidential appointees, we have little doubt that Congress could legitimately restrict Agriculture Department officers to those not convicted under the Meat Inspection Act." ${ }^{103}$ A district court cited Myers's "reasonable and relevant" test in Mow Sun Wong $v$ Hampton $^{104}$ for the proposition that Congress has the power to prescribe reasonable qualifications for at least inferior officers. ${ }^{105}$

A variant on Justice Kennedy's view was put forward in Justice Brandeis's dissent in Myers. Brandeis agreed that the Constitution permits some restrictions on appointments, but he employed a different rationale. He noted that while " $[t]$ here is not a word in the Constitution" that authorizes Congress to limit the President's range of nomination choices, Congress has enacted a "multitude of laws" that restrict his power to nominate, and every President has observed these laws." "A persistent legislative practice which involves a delimitation of the respective powers of Congress and the President, and which has been so established and maintained, should be deemed tantamount to judicial construction, in the absence of any decision by any court to the contrary." ${ }^{107}$ In short, long and extensive use and acceptance of qualifications and restrictions gives them legitimacy.

Legislative power ceases." Id, quoting 1 Annals of Congress 582 (Gales and Seaton 1834). Taft himself added the "reasonable and relevant" test. He may have based this idea on the extensive list of qualifications and restrictions in Justice Brandeis's Myers dissent, or in a colloquy Taft held with Solicitor General James Beck that Taft included in the opinion. Myers, 272 US at 96-97. Illustrating a point, Beck stated that "when the condition imposed upon the creation of the office has no reasonable relation to the office ... and is not the declaration of qualifications, but is the creation of an appointing power other than the President, then Congress has crossed the dead line." Id at 97.

100478 US 714 (1986).

101 Id at 740 (Stevens concurring).

102145 F3d 1369 (DC Cir 1998).

103 Id at 1372, citing Myers, 272 US at 128.

104435 F Supp 37 (N D Cal 1977).

105 Id at 41 n 6 . However, this case addressed a restriction-the exclusion of noncitizens from civil service-mandated by an Executive Order through delegated power, not by a direct act of Congress. Id at 40.

106 Myers, 272 US at 264-65 (Brandeis dissenting).

107 Id at 283, citing United States v Midwest Oil Co, 236 US 459, 469 (1915). 


\section{Restrictions on political party affiliation.}

Finally, the only two cases that directly addressed a political party restriction took a third approach and held the issue to be nonjusticiable. In FEC v NRA Political Victory Fund, ${ }^{108}$ the Federal Election Commission brought a civil enforcement action against the National Rifle Association's political action committee, which then challenged the constitutionality of the FEC on several separation of powers grounds. ${ }^{109}$ One of those claims was that the statute's requirement that no more than three of six members of the FEC may be affiliated with the same political party impermissibly limited the President's nomination power under the Appointments Clause. ${ }^{110}$ The court acknowledged that any such restrictions could raise constitutional questions, but found that it was "impossible to determine in this case whether the statute actually limited the President's appointment power." court first noted that Presidents have often viewed restrictions as not legally binding. ${ }^{12}$ Second, the court argued that the need for bipartisanship on the politically charged FEC imposed such political restraints on the President that he would not alter the commission's balance even if he were not constrained by the statute. ${ }^{113}$ Invalidating the restriction thus would not necessarily redress the NRA's claimed injury. ${ }^{114}$ The court did not specifically state that it was addressing the NRA's standing, but by raising redressability questions the court implicated standing doctrine. Standing appeared to be at issue when the court concluded that the issue might only be justiciable if the President appointed and the Senate confirmed a fourth same-party member, or if the President himself challenged the statute. ${ }^{1.5}$ In a second case, the Ninth Circuit followed NRA Political Victory Fund's conclusion that the issue was nonjusticiable. ${ }^{116}$

These holdings are open to significant criticisms. The argument that political restraints prevent the President from making unbalanced appointments is clearly undermined by the actual behavior when

1086 F3d 821 (DC Cir 1993).

109 Id at 822 . The court held that the presence of ex officio agents of the House and Senate on the commission unconstitutionally exceeded Congress's legislative authority. Id at 826-27.

110 Id at 823-24, citing 2 USC $\$ 437 \mathrm{c}(\mathrm{a})(1)$ (1988).

111 NRA Political Victory Fund, 6 F3d at 824 ("Appellants do not argue, nor can we assume, that the President wished to appoint more than three members of one party and was restrained by FECA from doing so.").

112 Id.

113 Id at 825 .

114 Id.

115 Id at $825 \& \mathrm{n} 4$.

116 National Committee of the Reform Party of the USA v Democratic National Committee, 168 F3d 360, 364-65 (9th Cir 1999). The court held that the issue could not be redressed when the Reform Party challenged the FEC's political party diversity requirement. Unlike NRA Political Victory Fund, the court here explicitly stated that standing was at issue. Id at 365. 
there is no statutory political party restriction. In those situations, Presidents rarely, if ever, make appointments on a strictly bipartisan basis. ${ }^{17}$ To claim uncertainty about the effect of the statute on appointments to the commission is thus unrealistic. ${ }^{118}$ In addition, these courts are confused about standing doctrine regarding constitutional challenges to administrative agencies. ${ }^{119}$ Courts need not limit standing to a President who wants to appoint a fourth member from a single party to the FEC. A plaintiff only has to show that he has "sufficient concrete interests at stake" to maintain standing to raise separation of powers questions. ${ }^{120}$ The D.C. Circuit interpreted this to mean that litigants have such standing when they are "directly subject to the authority of the [challenged] agency." ${ }^{121}$ As the plaintiffs in both cases were directly subject to the FEC's authority, the courts should have granted standing. ${ }^{122}$

Even if these two courts correctly held the FEC's political party restriction nonjusticiable, the cases cannot be generalized. The D.C. Circuit's argument about the need for bipartisanship on the politically charged FEC does not extend to agencies that do not regulate partisan political activity. In particular, it does not extend to an Article III court such as the CIT, which is insulated from political pressures.

Overall, the judicial record is too slim to draw any firm conclusions about the CIT's political party restriction. Furthermore, the few courts that have addressed restrictions generally have used different interpretive theories. An analysis of restrictions and qualifications

117 One need look no further than federal judicial appointments to reach this conclusion. See Gerald N. Rosenberg, Incentives, Reputation, and the Glorious Determinants of Judicial Behavior, 68 U Cin L Rev 637, 643-44 (2000) ("On average, approximately 90\% of federal court appointees are members of the same political party as the President who appoints them."). See also Brief for Respondents NRA Institute for Legislative Action, NRA Political Victory Fund, Grant Wills, FEC V NRA Political Victory Fund, No 93-1151, *49 (filed Sept 6, 1994), available on Lexis at 1993 US Briefs 1151 ("Respondent's Brief") ("[W]e are aware of no multimember board or Commission to which a President has made appointments on a strictly bipartisan basis in the absence of a statutory provision mandating such appointments.").

118 Respondent's Brief at *49.

119 See Raskin, 52 Admin L Rev at 614 (cited in note 3) (concluding that the D.C. Circuit's attempt to avoid the issue "badly misunderstands" relevant standing doctrine).

120 See Buckley $v$ Valeo, 424 US 1, 117 (1976) (granting standing to litigants challenging the method for appointing members of the FEC).

121 See Committee for Monetary Reform v Board of Governors of the Federal Reserve System, $766 \mathrm{~F} 2 \mathrm{~d} 538,543-44$ (DC Cir 1985) (holding that private businesses and individuals do not have standing to raise a constitutional challenge to the composition of the Federal Open Market Committee because they were not subject to the direct authority of the Committee or the Federal Reserve System).

122 Standing also would have been granted under a related Supreme Court standard. See Ryder v United Stutes, 515 US 177, 182 (1995) ("[O]ne who makes a timely challenge to the constitutional validity of the appointment of an officer who adjudicates his case is entitled to a decision on the merits of the question."). 
therefore must begin with first principles of constitutional construction.

\section{RESTRICTIONS UNDER FORMALISM}

Under a narrow formalist reading of the Appointments Clause, all statutory restrictions of any kind on the President's power to nominate are unconstitutional. This view derives from a formalist interpretation of the text and the structure of the Constitution, and accepted expressions of original intent. The Supreme Court's most extensive treatment of the question of restrictions reflects this perspective, and one could argue that a majority of the present Court is likely to adopt it. ${ }^{123}$ However, much of the formalist evidence is open to alternative interpretations, and a rigid application of the theory might require overturning dozens if not hundreds of laws. ${ }^{124}$ Nevertheless, an alternative but still formalist view of the evidence would not have such devastating consequences.

\section{A. Text and Structure}

Formalists use the Constitution's text and structure as the starting point for the argument that statutory restrictions on the President's power to nominate federal officers are impermissible. Formalists assert that the Appointments Clause is the only language in the text that provides for the appointment of officers and therefore consult no other provisions in deciding whether restrictions are valid. ${ }^{125}$ Furthermore, the clear grammar and language of this exclusive allocation of power does not permit any interference with the President's power to select a nominee. The Constitution explicitly allocates the power to nominate to the President alone and limits the Senate to advice and consent on the appointment decision. ${ }^{126}$ Therefore, any attempt by

123 See text accompanying notes 90-96. Chief Justice Rehnquist and Justice O'Connor joined Justice Kennedy's concurrence in Public Citizen. Justice Scalia, a leading formalist on the Court, did not participate in the case. Justice Thomas, also a formalist, was not on the Court at the time.

124 See text accompanying notes 71-88.

125 US Const Art II, $\$ 2$, cl 2. See Charles L. Black, Jr., The Presidency and Congress, 32 Wash \& Lee L Rev 841, 849 (1975) (noting that the President makes appointments under Article II); John M. Burkoff, Appointment and Removal under the Federal Constitution: The Impact of Buckley v. Valeo, 22 Wayne L Rev 1335, 1339-40 (1976) (stating that the Appointments Clause is the only positive source for the appointment power); William P. Barr, Common Legislative Encroachments on Executive Branch Constitutional Authority, 13 Op OLC 248, 248-49 (July 27, 1989), reprinted in H. Jefferson Powell, The Constitution and the Attorneys General 523, 523 (Carolina Academic 1999) ("These methods of appointment are exclusive.").

126 See Public Citizen, 491 US at 483 (Kennedy concurring) ("By its terms, the Clause divides the appointment power into two separate spheres: the President's power to 'nominate,' and the Senate's power to give or withhold its 'Advice and Consent."). See also Edmond v United States, 520 US 651,659 (1997) (noting that the Appointments Clause vests the President with the 
Congress to limit the President's range of choices is unconstitutional. ${ }^{127}$ All restrictions and qualifications are thus invalid, including the CIT's political party diversity requirement. As noted above, this view of the text and structure is reflected in Justice Kennedy's concurrence in Public Citizen. ${ }^{128}$ The fact that this interpretation would invalidate perhaps hundreds of organic statutes that include qualifications would not deter a formalist from adhering to the text. ${ }^{1.9}$

The key formalist assertions about constitutional text and structure can be challenged on several fronts. First, the text may not be as exclusive as formalists claim. While the Appointments Clause grants the President control over the nomination and appointment of officers, other provisions grant Congress power over the offices it creates. This power may allow Congress to set qualifications for those offices. The Necessary and Proper Clause grants Congress the power to create offices in order to execute the laws it passes. ${ }^{130} \mathrm{~A}$ range of authorities has argued that this power likewise permits Congress to fix restrictions for those offices. ${ }^{131}$ Two recent Supreme Court opinions that

"exclusive" power to select principal officers); John O. McGinnis, The President, the Senate, the Constitution, and the Confirmation Process: A Reply to Professors Strauss and Sunstein, 71 Tex L Rev 633, 638 (1993) ("[T]he act of nomination is separated from the act of appointment by a comma and a conjunction.").

127 The Justice Department's Office of Legal Counsel under President George H.W. Bush also advocated this view. See Barr, Common Legislative Encroachments at 250 (cited in note 125) (addressing statutes that require "a fixed number of members of certain commissions be from a particular political party" and finding them to violate the Appointments Clause). Reflecting this view, then-President Bush said in several signing statements that political party restrictions and other qualifications in the laws being signed had no legal force. See, for example, National and Community Service Act of 1990, Pub L No 101-610, 26 Weekly Comp Pres Doc 1833 (Nov 19, 1990), reprinted in 1990 USCCAN 4539 (stating that restriction is "without legal force"); Cranston-Gonzalez National Affordable Housing Act, Pub L No 101-625, 26 Weekly Comp of Pres Doc 1930 (Dec 30, 1990), reprinted in 1990 USCCAN 6231 (stating that the bill's restriction "does not constrain the President's constitutional authority to appoint officers of the United States"). Interestingly, the Barr memo was formally superseded in 1996, but the new opinion does not mention the prior view. Walter Dellinger, The Constitutional Separation of Powers between the President and Congress, 1996 OLC LEXIS 6 (May 7, 1996), reprinted in Powell, The Constitution and the Attorneys General at 617 (cited in note 125).

128491 US at 482-89 (Kennedy concurring).

129 See Printz v United States, 521 US 898, 918 (1997) (observing that the Court in Chadha held unconstitutional "perhaps hundreds" of federal statutes).

130 US Const Art I, \& 8, cl 18. See Buckley v Valeo, 424 US 1, 138 (1976) ("Congress may undoubtedly under the Necessary and Proper Clause create 'offices' in the generic sense."); Freytag $\nu$ Commissioner of Internal Revenue, 501 US 868, 883 (1991) (same); Shurtleff $v$ United States, 189 US 311, 313 (1903) (noting that Congress has the power to create the office of the Board of General Appraisers). For a general discussion, see Note, Congressional Power under the Appointments Clause after Buckley v. Valeo, 75 Mich L Rev 627, 639-44 (1977) (discussing congressional power under the Necessary and Proper Clause in the appointments context).

131 See Bowsher v Synar, 478 US 714, 740 (1986) (Stevens concurring) ("[I]t is entirely proper for Congress to specify the qualifications for an office that it has created."); Ex Parte Garland, 71 US 333, 378 (1866) (distinguishing private attorneys' mandatory oaths of office from oaths taken by public officials, the latter of which "may be burdened with any conditions not 
acknowledge Congress's power under the Necessary and Proper Clause to create offices have simultaneously imposed Appointments Clause restrictions on that power. ${ }^{132}$ Those constraints, however, were imposed not in the context of qualifications, but regarding direct appointment by Congress ${ }^{133}$ and appointment vested in a court of law. ${ }^{134}$ In short, the Necessary and Proper Clause provides a plausible though not conclusive alternative source of congressional power to set restrictions.

More particular to Article III courts, including the CIT, both Article I and Article III give Congress the power to create federal courts inferior to the Supreme Court. ${ }^{135}$ This power is more specific than that granted in the Necessary and Proper Clause, and could be construed to grant Congress even wider authority to restrict access to the judicial offices it creates. ${ }^{136}$ Congress has the authority to "constitute Tribunals inferior to the supreme Court," ${ }^{, 137}$ which relates to the inferior courts it may "ordain and establish" from time to time. ${ }^{138}$ First, these powers could be analyzed similarly to the Necessary and Proper Clause language. If so, however, the Appointments Clause limitations imposed by the Supreme Court could also be carried over to this language. ${ }^{139}$ Second, a literal reading of the text could lead one to conclude that

prohibited by the Constitution"); Amos T. Akerman, Opinion to the President on Civil-Service Commission, 13 Op Atty Gen 516, 520 (1871) (acknowledging that Congress has the power by direct legislation to prescribe qualifications for offices created by law). See also Note, 75 Mich L Rev at 641 (cited in note 130) (asserting that Congress should have the power under the Necessary and Proper clause to place limitations on the appointing authority's freedom of choice of nominees). Arguing that the ability to create an office gives Congress extensive power to stipulate qualifications, one commentator noted that it is "universally conceded that some choice, however small, must be left the appointing authority." Edward S. Corwin, The President: Office and Powers 1787-1957 74 (NYU 4th ed 1957). See also Edward S. Corwin, Tenure of Office and the Removal Power under the Constitution, 27 Colum L Rev 353, 391-92 (1927) (arguing that Congress has long exercised its power under the Necessary and Proper Clause to set qualifications for both inferior and principal officers).

132 See Buckley v Valeo, 424 US 1, 138-39 (1976) ("Congress' power under that Clause is inevitably bounded by the express language of Art. II, $\S 2$, cl. 2."); Freytag, 501 US at 883 (same, citing Buckley).

133 Buckley, 424 US at 137-43 (evaluating the appointment of members of the Federal Election Commission).

134 Freytag, 501 US at 883 (assessing the appointment of special trial judges by the Chief Judge of the Tax Court).

135 US Const Art I, \& 8, cl 9 ("The Congress shall have Power... To constitute Tribunals inferior to the supreme Court."); US Const Art III, $\S 1$ ("The judicial Power of the United States, shall be vested in ... such inferior Courts as the Congress may ... ordain and establish.").

136 The assertion that Congress may have more power to set qualifications for federal judges than for executive officers runs contrary to the policy of judicial independence established by Article III. Nevertheless, a literal textual reading might compel this conclusion.

137 US Const, Art I, $\$ 8, \mathrm{cl} 9$.

138 US Const Art III, § 1. See Glidden Co v Zdanok, 370 US 530, 543 (1962) (explaining that the Article I language refers to Article III inferior courts).

139 See text accompanying notes $132-34$. 
the power to "ordain and establish" inferior courts broadly confers the ability to set qualifications. Finally, Congress's significant discretion to determine the jurisdiction of inferior courts might argue for a similar power to dictate their composition. ${ }^{140}$ Like the Necessary and Proper Clause, these provisions offer another potential but equivocal textual basis for qualifications and restrictions.

In addition, the language of the Appointments Clause itself could be construed more broadly than formalists construe it. On its face, the text is simply silent on whether limitations are permissible. This silence could be filled by Taft's "reasonable and relevant" test from Myers or by an inference from two centuries of statutory qualifications. The text of Article II does not explicitly stipulate that the President's range of choice must be infinite, so formalists are forced to turn to evidence of original intent to demonstrate the clarity of the text. ${ }^{14}$

\section{B. Original Intent}

When the text and structure of the Constitution fail to settle a separation of powers question, formalists often turn to the original intent of the framers. ${ }^{142}$ A variety of sources are commonly used as evidence of their intent. None of these sources offers conclusive proof of specific original intent regarding appointments restrictions, and some are contradictory. However, one reflection of original intentcontemporaneous legislative enactments that extend until the present - is both a powerful challenge to the rigid formalist textual claim that no restrictions are permitted and an avenue for supporting an alternative formalist view that some restrictions are acceptable but the CIT's political party restriction is not.

An examination of accepted original sources - the proceedings of the Constitutional Convention, the Federalist Papers, and the debates and actions of the First Congress - reveals significant concern about where the appointment power should be lodged. Some invoke this evidence in support of a constitutional bar on restrictions, but it is far from definitive.

140 See Sheldon v Sill, 49 US 441,449 (1850) (holding that Congress may restrict the jurisdiction of lower federal courts).

141 Public Citizen, 491 US at 483 (Kennedy concurring) (examining the Federalist Papers for evidence of original intent).

142 See text accompanying note 50. Many formalists, however, see original intent as a far less reliable method of interpretation. See David M. Zlotnick, Justice Scalia and His Critics: An Exploration of Scalia's Fidelity to His Constitutional Methodology, 48 Emory L J 1377, 1392-98 (1999) (discussing Justice Scalia's "faint-hearted originalism" that does not use extratextual statements of the framers as authoritative sources of intent). See also Magill, $86 \mathrm{Va} \mathrm{L} \mathrm{Rev} \mathrm{at}$ 1138-39 \& n 40 (cited in note 45) (discussing the absence of consensus among formalists about using originalist sources). 
The background of the colonial period and the consequences of the Articles of Confederation strongly influenced the framers' views on the appointment power, particularly with respect to judges. ${ }^{143} \mathrm{Un}$ der British law, the Crown held exclusive power to appoint judges and other officers. ${ }^{144}$ This led to an extensive system of patronage, particularly in the colonies, where the appointment of unqualified officers "was a constant source of exasperation and anxiety in American society." 145 The British further fanned the flames by refusing to extend life tenure and salary protection to judges. ${ }^{146}$ Once the states achieved independence, they sharply limited executive involvement in judicial appointments. ${ }^{147}$ However, this led to abuse by state legislators. The patronage problem simply shifted to the legislatures, where the potential for corruption and political intrigue was strong. ${ }^{148}$ Nevertheless, some members of the Constitutional Convention preferred legislative to executive appointment. ${ }^{149}$ This conflict underscored the debate that followed.

The full history of the appointments debate is well-documented elsewhere ${ }^{150}$ but two elements are relevant to this Comment. First, it is clear that there was no consensus among the drafters about where the appointment power should lie. Two of the three plans formally introduced lodged the power in the legislature. ${ }^{151}$ Debate over the issue

143 For general discussions of this historical concern, see Theodore Y. Blumoff, Separation of Powers and the Origins of the Appointment Clause, 37 Syracuse L Rev 1037, 1044-57 (1987); Gordon S. Wood, The Creation of the American Republic 1776-1787 143-50 (Norton 1972); Bernard Bailyn, The Ideological Origins of the American Revolution 105-08 (Belknap 1967).

144 See Wood, Creation of the American Republic at 145 (cited in note 143).

145 Id.

146 The Act of Settlement of 1701 extended these protections to judges in England. See Blumoff, 37 Syracuse L Rev at 1048 (cited in note 143). Denying these protections to colonial judges inflamed revolutionary passions. See Bailyn, Ideological Origins at 105-08 (cited in note 143).

147 "In six states, the executive authority had virtually no role in the judicial appointment process." Blumoff, 37 Syracuse L Rev at 1055 (cited in note 143). Four states restrained their governors' participation through legislative councils, two required approval by councils elected by those qualified to vote, and New York established a separate Council of Appointment comprised of one member from each voting district and the governor. Id at 1056.

148 See Wood, Creation of the American Republic at 407 (cited in note 143) (noting that that legislators were "guided by no rules of law but only by their crude notions of equity"); Max Farrand, ed, 1 The Records of the Federal Convention of 1787119 (Yale 1966) (statement of James Wilson) ("Experience [showed] the impropriety of such [appointments] by numerous bodies. Intrigue, partiality, and concealment were the necessary consequences.").

149 Id at 119 (statement of John Rutledge) (expressing fear of granting so much power in one person).

150 See Blumoff, 37 Syracuse L Rev 1037 (cited in note 143).

151 See Farrand, ed, 1 Records at 21, 244 (cited in note 148); Max Farrand, ed, 2 The Records of the Federal Convention of 1787599 (Yale 1966). The Randolph plan lodged appointment power in the National Legislature, Farrand, ed, 1 Records at 21; the Pinckney plan gave it to Congress, Max Farrand, ed, 3 The Records of the Federal Convention 1787608 (Yale 1966); and the Patterson plan placed it in the Executive. Id at 244. Hamilton's plan, which he never formally 
spanned three months, with deep differences of opinion. The Convention soundly defeated a proposal that the President alone appoint judges, ${ }^{152}$ and the first vote on the proposal that the President nominate with the advice and consent of the Senate also did not garner a majority. ${ }^{153}$ The Convention also defeated Madison's proposal that executive nominations become appointments unless a majority of the Senate disapproved. ${ }^{154}$ It appears that the sentiment during much of the Convention leaned toward appointment by the Senate..$^{155}$ Nevertheless, the Convention in the end accepted without objection and with little debate the compromise that became the Appointments Clause. ${ }^{1.6}$ Without much evidence, it is risky to construct the rationale behind this shift by the drafters. It is sufficient to acknowledge the genuine divisions among them about the location of the appointment power.

The second relevant element of the debates is the absence of specific intent regarding qualifications. One goal of the framers was to give the power to the branch that would appoint the most qualified officers. Several believed the executive best for this task, ${ }^{157}$ while others favored the Senate's abilities. ${ }^{158}$ On the other hand, Madison in particular believed legislatures unlikely to make good appointments. ${ }^{159} \mathrm{Re}$ gardless of the framers' conflicting views on which branch would pick the most qualified candidate, they did not address the more specific question of whether the legislature could regulate any qualifications. ${ }^{160}$ Based on the framers' divergent views on the optimal locus of appointment power and the absence of specific intent regarding qualifi-

introduced, gave the power to the Executive, Farrand, ed, 1 Records at 244, with the Senate retaining the right to reject or approve nominees.

152 Farrand, ed, 2 Records at 44 (cited in note 151) (two states voted in favor, six voted against, and one was absent).

153 Id (noting four states in favor, four against, and one again absent).

154 Id at 83 (noting three states in favor, six against).

155 Id. The Convention voted six to three on July 21,1787 , for this plan, which was formalized in the Committee of Detail's report. Id at 183.

156 Id at 539 (approving the key language nem con (without objection)).

157 Farrand, 2 Records at 80 (cited in note 151) (Madison stating that the executive "would in general be more capable \& likely to select fit characters than the Legislature").

158 Id at 41 (Luther Martin stating that the Senate, "[b]eing taken from all the States, it [would] be best informed of characters \& most capable of making a fit choice").

159 Farrand, 1 Records at 120,232-33 (cited in note 148). Apparently observing the practice in states with legislative appointments, Madison found lawmakers to be "incompetent Judges of the requisite qualifications" and inclined to appoint judges "without any of the essential qualifications for an expositor of the laws." Id at 232-33. His solution based on this problem, however, was to give the appointment power to the Senate, "a less numerous [and] more select body." Id at 233.

160 See John R. Vile and Mario Perez-Reilly, The U.S. Constitution and Judicial Qualifications: A Curious Omission, 74 Judicature 198 (Dec/Jan 1991) ("[A] review of the convention debates and other contemporary sources reveals that almost no attention was paid to this issue."). 
cations, it is difficult to reach any conclusions from the debates of the Constitutional Convention.

The Federalist Papers offer strongly worded language that has been invoked to support a complete ban on restrictions and qualifications. ${ }^{161}$ The most direct statement is Hamilton's argument that "[i]n the act of nomination, [the President's] judgment alone would be exercised ... his responsibility would be as complete as if he were to make the final appointment." ${ }^{162}$ If this reflects the genuine intent of the framers, it is fairly persuasive. A President exercising only his own judgment and being permitted to act as if he were making the appointment alone should not be constrained by legislative restrictions. On the other hand, the foregoing account of the Constitutional Convention leads to doubts about using Hamilton as an accurate barometer of original intent. ${ }^{163}$

The acts and debates of the First Congress, which are often used to determine original understanding, also undermine the argument that the framers intended to bar all congressional restrictions and qualifications. $^{164}$ The First Congress established the first restrictions in the Judiciary Act of 1789, establishing residency requirements for federal district court judges and requiring that the Attorney General and District Attorneys be "a meet person learned in the law." visions limited the President's range of nominees, but there appears to have been no suggestion that they violated Article II. ${ }^{166}$ While this legislation is some evidence of original intent to permit qualifications for office, it may not be decisive. It is quite possible that the provision es-

161 See Public Citizen, 491 US at 483 (Kennedy concurring), citing Federalist 66 (Hamilton) and Federalist 76 (Hamilton), in Rossiter, ed, The Federalist Papers at 405, 456-57 (cited in note 44).

162 Federalist 76 (Hamilton), in Rossiter, ed, The Federalist Papers at 456-57 (cited in note 44). Speaking of the Senate's power of advice and consent on nominations, Hamilton said there will "be no exertion of choice" by the Senate and that "they cannot themselves choose" the nominee. Federalist 66 (Hamilton), in Rossiter, ed, The Federalist Papers at 405 (cited in note 44).

163 See text accompanying notes 143-160.

164 See, for example, Myers, 272 US at 111-32 (quoting extensively the debate over the Judiciary Act of 1789); Bowsher, 478 US at 723 (citing the "Decision of 1789" as "contemporaneous and weighty evidence" of the Constitution's meaning).

1651 Stat at $92-93$.

166 Currie, The Constitution in Congress at 43 (cited in note 73). When the First Congress passed this qualification, there apparently was no suggestion that it violated the Appointments Clause. Id. However, a member of the House objected the following year to a provision of a bill that required the Superintendent of Indian Affairs to be a military officer, saying that the restriction unconstitutionally infringed on the power of the President. Another member responded that the President and the Senate were restricted in their appointments of officers in several departments, including the Attorney General. Nevertheless, the provision was removed from the bill, although potentially for policy, not constitutional, reasons. Id at n 255; 2 Annals of Congress 152223 (Gales and Seaton 1834). 
caped the notice of members debating the many monumental issues in the bill or that its ramifications were not contemplated.

Nevertheless, the Judiciary Act of 1789 and the other later statutory restrictions offer an alternative formalist conception of restrictions. As noted above, the Supreme Court has repeatedly laid down the principle that "contemporaneous legislative exposition" in which the framers actively participated "fixes the construction to be given its provisions," especially when that interpretation has been "acquiesced in for a long term of years." ${ }^{, 167}$ This argument is essentially the position Justice Brandeis took when he dissented in Myers. ${ }^{168}$ The numerous qualifications imposed by Congress from the outset and the absence of significant objections therefore constitute weighty evidence in favor of finding at least some restraints on the President's appointment powers valid.

\section{An Alternative Formalist View}

A more refined formalist analysis treats some statutory qualifications as having stronger degrees of tradition and acquiescence and thus does not consider them equally valid under Article II. Formalism might therefore approve of some statutory restrictions but invalidate others. For the purposes of this Comment, the restrictions can be divided into two categories of tradition and acceptance.

The first category encompasses restrictions that can be traced to the framers and have been acquiesced in for many years. These include professional qualifications and residency requirements, which the First Congress imposed and successive Congresses have prescribed with little interruption or objection. ${ }^{170}$ Citizenship requirements also have a strong history, with the first one imposed in $1802 .^{171}$

The second category includes restrictions without the imprimatur of the framers and in which there has not been complete acquiescence. Political party restrictions, which did not appear until the creation of bodies that would later become independent agencies and have been challenged in court, fall into this category. ${ }^{172}$ The CIT's political party

167 Myers, 272 US at 175 (discussing statutes that allow removal of officers by the President and listing precedents). See also Printz, 521 US 898, 905 (1997), quoting Myers, 272 US at 175; Bowsher, 478 US at 723-24 (analyzing contemporaneous evidence to discern meaning).

168 See text accompanying notes 106-107.

169 An interpreter might also take into account the immense number of offices created by Congress without appointment restrictions. Those created with qualifications could instead be considered outliers from the constitutional norm.

170 See text accompanying notes 71-80.

171 Act of May 3, 1802, 2 Stat 195, 196 (providing that the mayor of the District of Columbia must be a citizen of the United States and a resident of the District). See also note 81 .

172 The antinepotism law and statutes that force the President to choose from a list provided by someone else are also in this category. 
restriction is an especially clear instance of a restriction in this category. It was not established until 1956, when Congress declared the CIT an Article III court, ${ }^{173}$ and the dispute in 1980 over whether to retain the provision may indicate an absence of strong acquiescence. ${ }^{174}$

Using this categorization, a formalist could validate the professional, residency, and citizenship requirements based on their long tradition. A formalist could also find all restrictions in the second category, including the CIT's political party restriction, in violation of the text of the Appointments Clause.

The CIT's political party restriction is thus likely to be found unconstitutional under formalism. The narrower version of formalism that only considers text, structure, and indicia of original intent is inconclusive. However, an alternative formalist model that accepts acts that the government has acquiesced to since the framing would classify the CIT's political party restriction as a violation of Article II's separation of powers.

\section{RESTRICTIONS UNDER FUNCTIONALISM}

Instead of examining only the text and structure of the Constitution and original intent of the framers, functionalism considers the extent to which statutory restrictions encroach on the President's power to nominate and whether the policies underlying the restrictions justify this intrusion. ${ }^{175}$ The Supreme Court's only balancing test for statutory restrictions is Myers's language limiting them to "reasonable and relevant qualifications and rules of eligibility of appointees." ${ }^{\text {"176 }}$ Courts must evaluate these statutes on a case-by-case basis to determine whether they are justified. Most restrictions will be found constitutional under this test, but the CIT's political party restriction fails it and thus violates the Appointments Clause.

The first step in the balancing test is to determine the extent of an encroachment on the President's constitutionally assigned power to nominate. ${ }^{177}$ Many statutory restrictions appear on their face to infringe significantly on the executive power. For example, professional qualifications - such as the requirement that members of the Commodities Futures Trading Commission have a demonstrated knowledge in futures trading or commodities ${ }^{178}$ - seem to limit severely the President's range of choices. This limitation may be somewhat illusory

173 See text accompanying note 24 .

174 See text accompanying notes $35-40$.

175 See Nixon, 433 US at 443 (presenting the balancing test for separation of powers questions).

176 Myers, 272 US at 129.

177 See Nixon, 433 US at 443.

1787 USC $\S 4 a(a)(1)(i)$. 
because in practice the President is not likely to want to nominate unqualified officers. Still, it can be argued that many statutory restrictions encroach on the President's constitutional power. The CIT's political party restriction likewise severely limits the President's range of choices. If the court already has five members from one political party, the statute will exclude from consideration the large percentage of the population from that party. Moreover, the President will almost always want to nominate a judge from his own political party, but the configuration of the court may force him under the statutory restriction to abandon those preferred choices.

Even if the infringement on executive power is significant, it might still be justified by policy rationales of "reasonable and relevant qualifications." For most statutory restrictions, the policy rationales are reasonable and relevant. It is easy to understand why Congress would want the Solicitor General to be learned in the law and CFTC commissioners to be knowledgeable about commodities or futures trading. Citizenship and residency qualifications are equally justifiable.

However, the CIT's political party restriction cannot be justified as a reasonable and relevant qualification. The idea of an independent judiciary is one of the most powerful and enduring values of the separation of powers. ${ }^{179}$ The framers sought to ensure an independent judiciary by granting judges life tenure and preventing any diminution of their salaries. ${ }^{180}$ The difficult task of impeachment was the only method permitted to remove federal judges. ${ }^{181}$ The Supreme Court has repeatedly and vigorously defended judicial independence. For example, the Court declared in 1982: "our Constitution unambiguously enunciates a fundamental principle - that the 'judicial Power of the United States' must be reposed in an independent Judiciary. It commands that the independence of the Judiciary be jealously guarded, and it provides clear institutional protections for that independence." ${ }^{182}$

179 See, generally, Archibald Cox, The Independence of the Judiciary: History and Purposes, 21 U Dayton L Rev 565 (1996) (describing America's long history of an independent judiciary).

180 US Const Art III, $\S 1$ ("The Judges, both of the supreme and inferior Courts, shall hold their Offices during good Behavior, and shall, at stated Times, receive for their Services, a Compensation, which shall not be diminished during their Continuance in Office.").

181 The Constitutional Convention rejected a proposal to allow removal by the executive and legislative branches. See Farrand, 2 Records at 428-29 (cited in note 151).

182 Northern Pipeline Construction Co v Marathon Pipe Line Co, 458 US 50, 60 (1982). The Court also outlined several justifications for an independent judiciary including: ensuring the independence of the judiciary from the control of the other branches, helping to promote public confidence in judicial determinations, providing the security necessary to attract well-qualified judges, and promoting individualism among judges. Id at 59 \& $\mathrm{n} 10$. See also United States $v$ Will, 449 US 200, 230 (1980) (holding repeals by Congress of previously approved salary increases a violation of the Compensation Clause of Article III). 
Statutory qualifications for judges on Article III courts such as the CIT impinge on their independence. Federal judges avoid identification with a particular party after they have been confirmed, regardless of the party of the nominating President. ${ }^{133}$ Forcing them to admit their party affiliation therefore intrudes on their strict independence. ${ }^{184}$ Forced association with a party may undermine public confidence in their impartiality. ${ }^{185}$ Formally designating judges as members of a particular political party may leave the impression that the judge is biased toward members of his or her party. ${ }^{186}$ Statutory qualifications also could influence judicial decisionmaking if judges feel that their nominations depended on an explicit quid pro quo obligating them to rule in favor of their party.

The policy arguments favoring political party qualifications for Article III judges fail to outweigh the infringement on judicial independence. During the debates over the Customs Courts Act of 1980, supporters of the CIT's political party restriction offered two justifications. First, they argued that since the restriction forced the President occasionally to "look outside his party for qualified candidates ... . a far larger and more diverse pool of talent would be drawn upon in making nominations." ${ }^{, 187}$ This rationale does not justify the restriction. The diversity of judicial talent should be accomplished by changes in the party in control of the presidency. ${ }^{188}$ Moreover, there is no limiting principle to this rationale. If forced presidential diversity can justify a political party restriction on the CIT, it should justify a similar restriction on all federal courts, including the Supreme Court. Such a statute would intrude on judicial independence (or at least the public's perception of it), and would significantly encroach on the President's power to nominate.

183 Concerns about mixing judges and politics are evident in codes of judicial conduct. See Canon 5: A Judge or Judicial Candidate Shall Refrain from Inappropriate Political Activity, ABA Model Code of Judicial Conduct 25 (2000) (proscribing judges' political behavior).

184 In rare instances, judges may be unable to express their genuine political orientation if doing so would unbalance the court in violation of the statute.

185 Consider Patricia M. Wald, A Response to Tiller and Cross, 99 Colum L Rev 235, 256 (1999) (arguing that the reputation of the federal judiciary will suffer if judges are forced to adopt party labels).

186 Id. At the CIT, where cases usually involve a private party against the federal government, formally affiliating judges with a political party may lead to the impression that the judge is biased in favor of the government if the judge's party is in power, or against the government if the judge's party is out of power.

187 See Customs Courts Act of 1980, HR Rep No 96-1235 at 134, reprinted in 1980 USCCAN 3729 (cited in note 25) (additional views of Representatives Robert McClory, Tom Railsback, Henry J. Hyde, and James Sensentrenner, Jr.).

188 See Patricia M. Wald, Last Thoughts, 99 Colum L Rev 270, 271-72 (1999) (noting in response to a proposal that appellate panels be required to be politically diverse that "the Constitution provides its own device for diversity over the long haul through the nomination and confirmation of federal judges by the political branches"). 
Second, the supporters argued that since the CIT makes international economic policy, it should represent a cross section of the "American body politic." political diversity on the Board of General Appraisers, which was to maintain a balance between members with a high tariff philosophy and those with a low tariff philosophy. ${ }^{190}$ This argument lacks a limiting principle and could thus be extended to the entire federal judiciary, particularly the Supreme Court, which also rules on trade issues. In addition, this rationale incorrectly assumes that party affiliation is an accurate proxy for views on issues likely to be before the CIT. In fact, both Democrats and Republicans have free trade and isolationist wings, making the political party restriction a poor way for Congress to achieve this diversity objective. Finally, this argument ignores the duty of impartiality expected of federal judges, ${ }^{191}$ which the framers sought in part to guarantee through the Article III protections. ${ }^{192}$ Judges should therefore make decisions based on the facts and law of cases, not on some role as a representative of a segment of the American body politic.

While a political party restriction on an Article III court is not justified under a functionalist approach, similar restrictions on administrative agencies and Article I courts present a more difficult question. If members of administrative bodies such as the Federal Communications Commission and the Securities and Exchange Commission exercised only executive powers, political party restrictions would be inappropriate. The vesting clause of Article II grants the President the power to select appointees who will carry out his policies. ${ }^{193}$ However, administrative agencies and Article I courts also exercise powers similar to Congress and federal courts, which could justify the use of political party restrictions.

Political party restrictions may be justified as a way to increase the accountability of administrative agency officials. ${ }^{194}$ Members of

189 Customs Courts Act of 1980, HR Rep No 96-1235 at 134 (cited in note 25) (additional views of Representatives McClory, Railsback, Hyde, and Sensenbrenner).

190 Customs Courts Act of 1980, Hearings on HR 6394 at 194 (cited in note 37) (statement of Andrew P. Vance).

191 Consider Laura E. Little, Loyalty, Gratitude, and the Federal Judiciary, 44 Am U L Rev 699, 711-15 (1995) (discussing judges' obligation to impartiality).

192 See Federalist 78 (Hamilton), in Rossiter, ed, The Federalist Papers at 465 (cited in note 44) (describing life tenure as "the best expedient which can be devised in any government to secure a steady, upright, and impartial administration of the laws").

193 See Myers, 272 US at 117 ("[T] he reasonable implication [of the constitutional mandate to take care that the laws be faithfully executed] ... was that as part of his executive power [the President] should select those who were to act for him under his discretion in the execution of the laws.").

194 The independence of federal judges is in part safeguarded by shielding them from this kind of accountability through Article III's protections. 
Congress are directly accountable to voters, who may defeat them at the polls in a subsequent election. Agency administrators who promulgate binding regulations are not nearly as accountable. They might therefore approve rules without regard to the public interest. Moreover, they may issue regulations with a bias toward the interests of the President, due to his relatively unfettered power to remove them for good cause. ${ }^{195}$ Political party restrictions may therefore be "reasonable and relevant" for administrative agency officials.

Political party restrictions also may limit the bias of administrative bodies acting as court-like adjudicators. Agency adjudicators might skew their decisions in favor of a President who has some removal power. Political party restrictions would force the President to appoint politically diverse administrative agency officers, and could be justified as an attempt to make the agencies less likely to be biased. ${ }^{190}$ In short, political party restrictions can thus be justified as a way to prevent the President from turning quasi-legislative and quasi-judicial bodies into partisan units that deny justice and benefits to members of other parties.

\section{CONCLUSION}

The Court of International Trade's unique political party restriction violates the Appointments Clause under either a formalist or functionalist separation of powers theory. A narrow formalist view that only considers the text and structure of the Constitution does not sufficiently address the issues raised by statutory restrictions, as the text and structure are neither clear nor exclusive. A formalist interpretation would also lead to the invalidation of hundreds of restrictions and qualifications of various offices. A broader formalist view that encompasses legislative enactments that reflect the intent of the framers is more forceful. Certain restrictions reflect the original intent and are valid, while those without the framers' imprimatur-including the political party diversity requirement of the CIT - are not. This strain of formalism also does not lead to the invalidation of so many statutory provisions.

195 See Marshall J. Breger and Gary J. Edles, Established by Practice: The Theory and Operation of Independent Federal Agencies, 52 Admin L Rev 1111, 1144-46 (2000) (noting that many commentators believe there to be a wide variety of reasons for which independent agency officials may be removed "for cause").

196 On the other hand, agency adjudicators are likely to be the most shielded by "for cause" restrictions, so political party restrictions may be less needed. See Dellinger, The Constitutional Separation of Powers, 1996 OLC LEXIS 6 at *148-49 (cited in note 127) (arguing that "for cause and fixed term limitations on the power to remove officers with adjudicatory duties affecting the rights of private individuals will continue to meet with consistent judicial approval"). 
The functionalist viewpoint also invalidates the CIT's restriction, and may be marginally better at contending with restrictions and qualifications in general. Functionalism's balancing test allows for a case-by-case analysis of restrictions. Based on the very few challenges raised to date, this task should not overwhelm courts. The bright line rule sought by Justice Kennedy in Public Citizen is therefore not necessary. A functionalist approach also would not instantly invalidate any statutes, as would either type of formalism. However, functionalism would not be as proficient at settling the hardest cases-political party restrictions on administrative agencies-and could lead to mixed and confused holdings.

In the end, the CIT's political party restriction violates the Appointments Clause regardless of the theoretical perspective used. It is an unjustifiable anachronism that should be eliminated. 